\title{
IMPACT OF CLAIMS SETTLEMENT ON THE DEVELOPMENT OF NIGERIAN INSURANCE INDUSTRY (2007-2017)
}

NWITE SUNDAY C. Ph.D ACII, ACIB, IRDI

Department of Banking and Finance Ebonyi State University, Abakaliki E-MAIL: sunnynwite@gmail.com

OKPARAKA VINCENT C (Ph.D)

Department of Insurance and Risk Management Enugu State University of Science and Technology E-MAIL: vincentokparaka@yahoo.com OKEKE DANIEL C.

Department of Insurance And Risk Management Enugu State University of Science and Technology E-MAIL: dokeke38@gmail.com

Claims settlement is a critical part of insurance contract, because it is vital to both the policyholder and the insurance company. This paper examines the Impact of Claims Settlement on the Development of Nigerian Insurance Industry (2007 - 2017). The objectives of the study include: to estimate the impact of total claims settlement on Insurance penetration in Nigerian, and to estimate the impact of total claims settlement on insurance density in Nigerian. The research design used was Ex-post facto research design. While Ordinary Least Square (OLS) regression method was utilized for data analysis. It was discovered that: total insurance claims had positively but insignificantly impacted on insurance penetration in Nigerian with p-value of [0.606]. While, total insurance claims had positively and significantly impacted on Insurance density in Nigerian with p-value of [0.007]. From the result of model one, the $\left(\mathrm{AR}^{2}\right)$ was -.097 ; this implies that only $-9.7 \%$ of the total changes or variations in insurance penetration in Nigeria could be explained by total insurance claims settlement in Nigeria. While from the result of model two the $\left(\mathrm{AR}^{2}\right)$ was 0.619 ; this implies that $61.9 \%$ of the total changes or variations in insurance density in Nigeria could be explained by total insurance claims settlement in Nigeria. Based on these results the study concludes that claims settlement had impacted positively on the development of Nigerian Insurance Industry. Thus, it was recommended that: Insurance companies should have effective and efficient claims department equipped with modern technology and qualified claims manager(s) to oversee the management and settlement of valid claims of their policyholders in order to increase insurance penetration in Nigeria; Nigerian Insurance Industry regulators should enhance its supervisory frameworks to ensure that genuine claims are promptly settled by insurance companies and defaulter adequately punished. This will have positive impact on insurance density because more Nigerians will be encouraged to buy insurance policies. In line with the theoretical framework adopted for this study, and in addition to settlement of valid claims, insurance companies should periodically carry out marketing research to discover the insurance needs of their customers as well as prospective customers through product revitalization and new product development to increase customers' expected utility for buying insurance. This will encourage Nigerians to purchase more insurance, and in turn enhance the development of Nigerian Insurance industry.

Keywords: Claims Settlement, insurance penetration, insurance density, insurance development 


\section{INTRODUCTION}

\subsection{Background to the syudy}

The origin of modern insurance in Nigerian can be traced to the activities of European merchants in the West African coast. This was influenced by two factors; first, the expansion of cash crop production for exports, and the upward surge in economic activities in the 1890s; second, the British desire to protect its interest and properties in the protectorate of West Coast Africa.

According to Nwite (2005), increased trade in Nigeria led to increased activities in shipping and banking, and it soon became necessary for foreign firms to handle some of their risks locally. The first insurance agency in Nigeria was the Royal Exchange Assurance Company introduced by African and East Trade Companies (Nwite, 2005).

The enactment of Workmen's Compensation Ordinance of 1942 and the Road Traffic Act of 1945 both contributed to the meaningful take-off of insurance industry in Nigeria. The Nigerian economy at that time depended so much on agriculture, so the major risk the European merchants were confronted with, was the risk of transporting their cash crops to Europe. This accounted largely for the dominance of marine insurance in the country as at that time. The National Insurance Commission in September 2005 set in place capitalization requirements for insurance companies operating in Nigeria.

The Commission stipulated 2bn Naira for life insurance, $3 b$ Naira for general insurance, and $5 \mathrm{~b}$ Naira for composite insurance or have their operating licenses revoked. Insurance companies were given till February 27, 2007 to comply with the new directives. Consequently, out of the 104 insurance companies and four reinsurance companies that existed before the reforms, only 49 underwriters and two reinsurers met the new capital requirements and were certified by NAICOM in November 2007.

Recapitalization of the insurance in Nigeria has no doubt resulted to a colossal increase in the volume of business, for instance, the sector was able to pull an aggregate gross premium income of $90 \mathrm{~b}$ Naira in 2007, over $18 \%$ more than was obtained in 2005. Growth in premium maintained an upward trend of 25\% in 2008 and 30\% in 2009 (Nigerian Insurance Report, 2010).

When a person buys a product, his major concern is whether that product will be fit for the purpose for which he is buying it. More often than not, he would have satisfied himself by inspecting the product and testing that it is performing before he actually buys the product. In so far as insurance is concerned, there is no physical product to test (Agu, 1999).

What the policyholder buys is just a promise to pay a claim arising after the purchase and in accordance with the insurance policy sold. The actual test does not come until such a claim comes up from the insured or other party concerned. If the insurer at that time makes good his promise, the insured is satisfied that he made a good buy. Where the insurer fails, the policyholder is dissatisfied.

The policyholder's dissatisfaction may result in severe cost for the insurer. He may feel so badly hurt that he may route for legal action which more often than not result to bad publicity for the insurer. In other words, the claim settlement decision of an insurer can make or mar its fortunes. 
Claim is an important aspect of insurance business because bad claim settlement records of an insurance company may bring disaster for such a company while a good reputation for claim settlement on the other hand may mean prosperity with regard to acquisition of more business." Nigerian Insurance industry will experience growth and development provided that they are prepared and ready to settle all genuine claims on time.

That the image problem suffered till today by insurance companies in Nigeria is mainly because of what is seen as the insurance companies' attitude of "smile to collect premium and frown to pay claim. The insuring publics do not even trust the insurers because they believe that they would always look for a way out at time of payment even when the claims are genuine (Oshinloye, 2009).

It is used to be said that insurers would do anything possible to squirm out of paying claims (Unachukwu, Afolabi \& Alabi, 2015). If an insurance company does not effectively handle its claims services, it can ruin its image, and hence affect the sales and marketing of its insurance products. Braers (2004) states that a company, which fails to settle genuine claims, would categorically attract less business, as it is likely to dishearten such clients from continuing to patronize the company. Such customers might even advise their friends, colleagues and relations not to patronize such a company.

Thus, prudent claims administration strategy promotes customer contentment and allegiance, as it helps to develop a perception of membership or belonging within a particular group of customers, thereby providing the company with opportunities to retain existing customers while attracting new ones and profitable ones. In other words, claims settlement is the activity of insurance companies that truly portrays what they are there for.

Many studies establish that prompt claims settlement contribute to organization performance. For instance, Butler and Francis (2010) discover that prompt claims settlements has positive and significant relationship with insurance performance in terms of customer satisfaction and loyalty.

They opine that one of the reasons for low penetration of insurance business in most countries is due to insurers' delay in settling claims. Insurance business is based on trust but is weighed down with fraud as perpetrated by various actors in the Nigeria insurance industry. Daniel (2013) also asserts that failure to settle claims and delay claims settlement are the causes of insurance failure in Nigeria.

Hewitt (2006) also states that prompt claims settlement by insurance companies influence customer loyalty in advance countries. However, findings of Bates and Atkins (2007) and Ndubuishi (2008) conflicted with previous studies. They discovered that claims payment could be very costly as claims constitute the largest cost of an insurer and this has contributed to poor performance of insurance companies.

This study therefore is set out to investigate whether claims settlement had impacted positively on the development of Nigerian Insurance Industry between the periods 2007 to 2017.

\subsection{Statement of Problem}

A claim is the payment made by the insurance company to the insured or a representative of the policyholder on the happening of the event specified in the contract, in return for the 
premiums paid by the policyholder.

Claim settlement is the crucial moment in the relationship between insurance companies and their customer as it creates the opportunity to prove that the money used up paying premiums were worth the expense. In the same vein, claim provides an insurer the opportunity to make a favorable impression on the policyholder. The reputation of any insurance company depends considerably on the sort of claims services provided by that insurance company to its policyholders.

Therefore, effective claims management and prompt settlement of valid claims is an important function of insurance companies. It is therefore expected that insurers should always fulfill their promises whenever the insured or a claimant who had abided with all the terms and condition of an insurance contract comes up with genuine claim.

Insurance companies' attitudes to claims settlement has in the past roused a lot of public denigration and attracted the attention of government (Harry, 2012). Even in recent times, it is noticed that there are still traces of claims disputes due to unnecessary delay and repudiation of valid claims by some insurers in the Nigerian Insurance Industry.

In many cases, insurance claims had been shorn of by the insurer for the reason that the insured or claimant failed to follow some steps and not able to submit the necessary information to the company within the stipulated time or because of deliberate acts of fraud by some insurance companies and their representatives. Worthy of note though, is the tremendous improvement in claims settlement in the Nigerian insurance industry because of increased regulation, supervision and recapitalization of the industry over the last twelve years.

Yusuf and Dansu (2014) state that claims from previous years usually surface in succeeding years, which makes the insurance businesses challenging and the attainment of profitability, very difficult. The Nigerian insurance industry has witnessed rising claims from policyholders. At the end of June 2017, the reported claims in the financial statements of 22 major leading insurance companies showed claims expenses to be over N40 billion as against N34.1 billion in the previous year (Vanguard, 2017). This is a 17.3 percent growth, which when compared with the 8.76 percent growth in premium income, recorded in same periods, calls for concern. Claims paid by insurance companies represent the largest single cost to insurers, and 80.0 per cent of all premiums are spent on claims payment and associated handling charges (Butler and Francis, 2010).

Nigerian Insurance Industry has recorded remarkable development since its last recapitalization in 2007 and a lot of factors could be responsible for this positive stride. Could claims settlement be one of the endogenous factors responsible for insurance development in Nigeria? This study therefore is set out to investigate whether claims settlement had impacted positively on the development of Nigerian Insurance Industry between the periods 2007 to 2017 with specific interest on insurance penetration, insurance density, and total claims settlement of the Nigerian insurance sector. "

\subsection{Objectives of the Study}

The broad objective of this study was to study the impact of claims settlement on the development of Nigerian Insurance Industry from 2007 to 2017. While the specific objectives of the study include to: 
1. estimate the impact of total claims settlement on Insurance penetration in Nigerian; and

2. estimate the impact of total claims settlement on Insurance density in Nigerian.

\subsection{Research Questions}

The following research questions were put forward in order to find out how claims settlement had impacted on insurance development in Nigeria.

1. To what extent had total claims settlement impacted positively on Insurance penetration in Nigerian?

2. To what extent had total Claims settlement impacted positively on Insurance density in Nigerian?

\subsection{Research Hypotheses}

The following null Hypotheses were postulated in line with the objectives of the study.

Ho1 Total claims settlement had not impacted positively and significantly on Insurance penetration in Nigerian.

Ho2 Total claims settlement had not impacted positively and significantly on Insurance density in Nigerian.

\section{REVIEW OF RELATED LITERATURE}

\subsection{Conceptual Review}

\subsubsection{Concept of insurance Claims}

The word "claim" according to Kapoor (2008) cited in Yusuf \& Abass (2013) emanated from the Latin word, "Clamare" which means to "call out".

The Farlex Financial Dictionary (2009) defines claims as a formal request to an insurance company asking for a payment based on the terms of the insurance policy. It defined a claims form as a document or request filed by a policyholder stating that an insured event has occurred and that the insurance company should provide compensation or the agreed benefit. Insurance claim is a notification to an insurance company requesting payment of an amount due in accordance with the terms of the policy.

Barry (2011) defined insurance claims as all activities geared towards monitoring insured's compensation, restitution, repayment or any other remedy for loss or damage or in respect of doing their obligations. According to Williams (2009), claims are all about insurance and insurance is about taking up the liability or risk of the insured against a loss and when this is done, the insured would in return get a claim as compensation for the loss.

Irukwu (1989) defines insurance claim as an insurance extract in which the insurer undertakes to indemnify the insured against a loss, which may or may not arise at a future date or to pay a certain amount of money on the occurrence of a certain specified event(s). The loss that is insured against is known as the insured risk.

He further emphasized that the primary duties of the insured under the insurance contract are to pay the agreed premium and to comply with the terms of the policy while the duty of the insurer is to comply with his own terms and promises under the policy and to pay or settle all genuine claims promptly and equitably. A Claim is an official request submitted to the insurance company demanding payment as per the terms of the policy.

Insurance claim is a notification to an insurance company requesting payment of an amount 
due under the terms of the policy. Claim is request for reimbursement from the insurance company when the insured has suffered a loss that is covered under an insurance policy.

\subsubsection{Concept of Claims Settlement}

Marquis (2011) posits that insurance Claims Settlement consists of the departmental stipulation, corporate policies and industry practices that insurance firms use to validate policyholder payment or reimbursement requests.

Supporting this definition, Gallagher (2012) opines that Claims Settlement involves administration of claims arising from loss events. Claims handling is the moment of truth for the insurance industry, an opportunity to fulfill the promise made to customers to pay a valid claim (Hewitt, 2006). The essence of its actual application is to bring into play the benefit of the insurance promise (Kapoor, 2008).

The main objectives of claims management, according to Redja (2008), are to verify that a covered loss has occurred for fair and prompt payment of claims and to the insured.

\subsubsection{General Claims Settlement procedure}

According to Oluoma, (1999) all insurance policies contain a condition which lays down the procedure to be followed in the event of a loss, and the insured should in his own interest comply with this procedure.

The general procedures involved in the management of Claims include:

Notification of Claims: Insurers as a first step usually require the insured to notify them of the occurrence of the loss or events likely to give rise to claim (Oluoma, 1999).

Proof of Loss: Following the notification, the insured must supply the details or particulars of loss to the insurer. Indeed the burden of proof of the loss rests solely on the insured, who has to convince the insurers with supporting documents or evidence to prove that he is entitled to claim under the policy. In fact, he has to satisfy the insurer not only that a loss had occurred, but that it is a loss 'covered by an insured peril, and if he fails to prove the loss, his claim is bound to-fail.

Investigation: On receipt of the notice and details of the loss, the insurer may wish to investigate the loss. This is to establish whether the loss actually occurred and to know whether it falls within the scope of the policy they covered. Thus, a thorough investigation may be necessary. In fact, since the insurer is holding the insurance fund on behalf of all policyholders, any payments, therefore should be entirely justified (Oluoma, 1999).

Settlement of the Claims: Finally, where all the information obtained and the investigation carried out by the insurer reveal that there is a liability on the insurer, payment should be made immediately, once the claim is discovered to be valid. Where a claim is admitted, settlement might be made by cash, replacement, repair or reinstatement.

However, where a claim is not admitted, the insurer has to inform the insured or claimant of their intention instead of undue delays which might as well earn them bad image (Oluoma, 1999).

\subsubsection{Concept of Insurance Development}

According to Cambridge Dictionary (2019), development is the process in which someone or 
something grows or changes and becomes more advanced. It is the process of growing or creating something over a period of time.

Development is a process that creates growth, progress, positive change or the addition of physical, economic, environmental, social and demographic components. The purpose of development is increase in the level and quality of life of the population, and the creation or expansion of local regional income and employment opportunities, without damaging the resources of the environment.

Development is visible and useful, not necessarily instantaneously, and includes an aspect of quality change and the creation of conditions for a continuation of that change. For the purpose of this study, two development indicators (Insurance Penetration and Insurance Density) were used to measure the level of development of Nigerian insurance industry.

\subsubsection{Insurance Penetration}

Insurance penetration indicates the level of development of insurance sector in a country. It is measured as the ratio of premium underwritten in a particular year to the GDP. Insurance Penetration - refers to a product's sales volume relative to the sales volume of competing products. Within insurance, there is life insurance penetration which considers premiums from life insurance policies only as a percentage of GDP and non-life insurance penetration which considers premium from other than life insurance policies like auto insurance, health insurance, etc.

Insurance penetration measures the input of insurance premium to the Gross Domestic Product (GDP) of a country in percentage terms. For instance, if a country generates a total insurance premium say, USD10 billion and that country's GDP for the same period is USD100 billion, insurance penetration translates to 10\% (Onifade, 2016).

Insurance penetration refers to a product's sales volume comparative to the sales volume of competing products, usually expressed as a ratio of premium to another financial measure like Gross Domestic Product (Jeff, 2016).

\subsubsection{Insurance Density}

Insurance density is calculated as the ratio of premium (in Naira) to total population. Insurance Density - refers to a product's number of customers by geographic area (country, state etc.) usually expressed as a proportion of premium to population.

The measure of insurance density reflects the level of development of the sector (Jeff, 2016). Insurance density is the ratio of insurance premium to the total population. It gives an indication of how much each person in Nigeria spends on insurance in terms of premium. In other words, it is the per capita premium for the country, estimated by dividing the total insurance premium by the population.

For example, if the total insurance premium is USD10 billion and the population of the country is 10 million people (Onifade, 2016).

\subsection{Theoretical Framework}

This paper adopted Expected Utility Theory as the theoretical framework. This theory was propounded by Daniel Bernoulli in (1738) as a tool to solve the St. Petersburg Paradox. 
The theory is used to estimates the likely utility of an action - when there is uncertainty about the outcome. It advocates that, rational choice is to choose an action with the highest expected utility. Expected utility theory is used as a tool for analyzing situations where individuals must make a decision without knowing which outcomes may result from that decision, i.e., decision making under uncertainty.

These individuals will choose the action that will result in the maximum expected utility, which is the sum of the products of probability and utility over all the possible outcomes. The decision made will also depend on the person's risk aversion and utility over other agents. This theory notes that the utility of money is not essentially the same as the total value of money.

This explains why people may take out insurance policies to cover themselves for the variety of risks. The expected value from paying insurance premium would be to lose out monetarily. But, the possibility of large-scale losses could lead to a serious decline in utility because of diminishing marginal utility of wealth.

The choice of this theory was based on its usefulness in evaluating situations without immediate payback, such as decisions to buy insurance. When one weighs the expected utility to be gained from making payments in form of insurance premium to insurance company for a guaranteed income or compensation at the happening of an insured contingency and the expected utility of retaining the premium amount and spending it on other opportunities and products, insurance seems like a better option.

\subsection{Empirical review}

Afolabi (2018) studied the Effect of Claims Payments on Profitability in The Nigerian Insurance Industry for the periods 2011 to 2016 using descriptive statistics and the multiple regression techniques. Profitability determines an insurance company's ability to make claims payments as at when due. The result reveals that ROA (profitability) has an indirect relationship with LR (loss ratio) and NC (net claims), but a direct relationship with ER (expense ratio). It further reveals that net claims have a significant positive impact on loss ratio.

Caren and Muwangi (2017) investigated the effect of underwriting and claims management practices on the performance of general insurance firms in East Africa from 2010 to2014. The study employed multiple linear regression analysis using primary and secondary data collected from 82 general insurers in Kenya, Uganda and Tanzania.

The findings confirm that there is a significant positive relationship between underwriting and claims management practices employed by the firms and non-financial performance, but the relationship with financial performance was insignificant. The implication is that a profit oriented insurance firm should embrace a claims function that is closely related with the underwriting and pricing of the firm's portfolio for meaningful results. It is recommended that general insurance companies focus on other important factors besides underwriting and claims management order to improve overall financial performance.

Unachukwu, Afolabi and Alabi, (2015) investigated and critically analyzed the effect of claims settlement on the performance of Nigerian insurance companies with special reference to the selected insurance companies in Ilorin metropolis. 
Structured questionnaire was used to collect data from 5 selected insurance companies' staff, 4 insurance brokers, 15 sales agents and 21 public through purposive method totaling 45 respondents as sample for the study. Linear regression analysis was employed to analyze data collected with aid of Statistical Package for Social Science (SPSS). The result of the research carried out has confirmed that prompt claims settlements has positive significant effect on customer satisfaction and loyalty respectively. Moreover, the result indicated that prompt claims settlements has more influence on customer satisfaction than loyalty.

Yusuf and Dansu (2014) examined the relationship between claims cost and profitability in the Non - life sector of the Nigerian insurance industry. The study developed two linear regression models used to forecast future events in the industry. Data were generated from the financial reports of ten (10) insurance companies covering a period of ten years $(2002-$ 2011). These data were analyzed using descriptive statistics, coefficient of determination (R2), ANOVA (F), standard error test, test of correlation (T), multiple linear regression and ordinary least square Regression techniques. In addition, two hypotheses were also tested. The results revealed that PBT (profitability) correlates directly with NC (Net Claims) and ER (Expense Ratio) but correlates inversely with LR (Loss Ratio).

Oyekan (2013) examined factors that influence the profitability of micro-life insurance firms in Nigeria and South Africa. In particular, the joint impact of cost efficiency, ownership structure, leverage and reinsurance together with other institutional factors, on the profitability of commercial micro-life insurance providers are investigated. The cost efficiency estimates are derived using two main frontier efficiency estimation techniques; data envelopment analysis (DEA) and stochastic frontier analysis (SFA) in a first-stage analysis. Using the FGLS estimator in a panel of 61 firms over the period covering 2005 and 2010 , the study supports as well as contradicts the results of prior studies. No statistically significant relation between ownership structure and the profitability of micro-life insurers for all the stock-ownership firms considered.

Kalani, Salunkhe and Ahirrao (2013) examined claim settlement ratio of LIC with other insurance companies in India using survey design. Study observed that there are cases of frauds in claim settlement that may happened but if the policyholder uses proper precautions he will prevent himself from fraud. LIC of India provides better corporate services for settling the customers claim. D-mat may improve transparency and efficiency of the claim settlement. Authors studied comparison of claim settlement ratio of LIC with other life insurance industry and survey of policyholders and opinions regarding claim settlement.

Ofori-Attah (2012) undertook a study on the effects of slow claims settlement on the sales and marketing of Insurance products; a case study of Enterprise Insurance Co. (EIC) Ltd Takoradi branch, Ghana. This research investigated the trends in the company's (Enterprise Insurance Company Ltd) claims settlement system and its effect on the sales and marketing of its insurance products. The results obtained from the data collection were cross tabulated and subjected to descriptive analysis. The results obtained established the fact that prompt and satisfactory claims payment had positive effects on the sales and marketing of insurance products and vice versa. 


\subsubsection{Summary of Empirical Literature \\ Table 2.1Summary of Empirical Literature}

Author

Afolabi (2018)
Title

Effect of Claims Payments on Profitability in The Nigerian Insurance Industry.

$\begin{array}{ll}\text { Methodology } & \text { Findings } \\ \begin{array}{l}\text { Ex-post } \\ \text { facto/Descriptive The result reveals } \\ \text { statistics and }\end{array} & \text { that (profitability) has an } \\ \text { multipleregression } & \text { indirect relationship } \\ & \text { with LR (loss ratio) } \\ & \text { and NC (net claims), } \\ & \text { but a direct } \\ & \text { relationship with ER } \\ & \text { (expenses ratio). }\end{array}$

Caren and Muwangi Effect of underwriting and Ex-post (2017)

claims practices management performance of general insurance firms in East Africa.

Unachukwu, Afolabi and Alabi (2015)

The effect of claims settlement on the performance of Nigerian insurance companies with special reference to the selected insurance companies in Ilorin metropolis

Yusuf and Dansu (2014)
Examined relationship claims profitability in the Non life sector of the Nigerian Insurance industry.

Claim settlement ratio of Survey design Life Insurance Companies in India. the -post facto / Linear Regression
There is a significant positive relationship between underwriting and claims management practices employed by the firms and non-financial performance.

Survey method / Prompt claims Linear Regression settlements has positive significant effect on customer satisfaction and loyalty respectively
Kalani, Salunkhe and Ahirrao (2013)
For every one percent increase in Net Claims, there will be a corresponding increase of $36.7 \%$ in Loss Ratio.

There are cases of frauds in claim settlement that may happened but if the policyholder uses proper precautions he will prevent himself from fraud. 


\section{Table 2.1Contd.}

Oyekan (2013)

Ofori-Attah (2012)

\section{Summary of Empirical Literature}

$\begin{array}{lll}\text { Examines the factors } & \text { Ex-post facto / Data } & \text { No statistically } \\ \text { that influence the envelopment analysis, significant relation } \\ \text { profitability of micro-life } & \text { Stochastic frontier between ownership } \\ \text { insurance firms in analysis and Panel structure and the } \\ \text { Nigeria and South Africa data } & \text { Feasible profitability of } & \text { of } \\ & \text { generalised least micro-life insurers } \\ & \text { squares estimator } & \text { for all the stock- } \\ & & \text { ownership forms } \\ & & \text { considered }\end{array}$

$\begin{array}{lll}\text { Effects of slow claims } & \text { Survey method / Prompt and } \\ \text { settlement on the sales Percentage } & \text { satisfactory claims } \\ \text { and marketing of } & \text { payment had positive } \\ \text { Insurance products; a } & \text { effects on the sales } \\ \text { case study of enterprise } & \text { and marketing of } \\ \text { insurance co. ltd (EIC)- } & \text { insurance products } \\ \text { Takoradi branch } & \text { and vice versa }\end{array}$

\subsubsection{Gap in Literature}

Based on the summary of empirical literature reviewed, the gap in literature that gave credence to this work was that the empirical studies reviewed focused on effect of claims settlement on profitability, financial performance or fraud.

While this study focused on impact of claims settlement on the development of Nigerian Insurance Industry (2007 - 2017) using insurance penetration and insurance density as proxies for insurance sector development.

\section{METHODOLOGY}

\subsection{Research design}

Ex-post facto research design was adopted for this study. This is a type of research design in which the investigation starts after the fact has occurred without interference from the researcher.

\subsection{Nature and sources of Data}

Secondary data were used for this study. Data were gathered from Central Bank of Nigeria Statistical Bulletin and National Insurance Commission's annual publication of various years.

\subsection{Model specification}

The model adopted was stated as follows:

\section{Hypothesis one}

Total claims settlement had not impacted positively and significantly on Insurance penetration in Nigerian.

The functional relation of the model was given as: $\mathrm{IP}=\mathrm{f}(\mathrm{TIC}) \ldots$ Eqn (i)

The model is specified as follows: $\mathrm{IP}=\beta 0+\beta 1 \mathrm{TIC}+\mu \ldots$ Eqn (ii)

Where: IP = Insurance Penetration,

TIC $=$ Total Insurance Claims, 
$\beta 0, \beta 1=$ Constant parameters, $\mu=$ the error term

\section{Hypothesis two}

Total claims settlement had not impacted positively and significantly on Insurance density in Nigerian.

The functional relation of the model was given as: ID $=\mathrm{f}(\mathrm{TIC}) \ldots$ Eqn (iii)

The model is specified as follows: ID $=\beta 0+\beta 1 \mathrm{TIC}+\mu \ldots$ Eqn (iv)

Where: ID = Insurance Density;

TIC = Total Insurance Claims;

BO, $B 1$ = Constant parameters;

$\mu=$ the error term

\subsection{Description of model variables}

\subsubsection{Independent variable}

Total insurance claims: This refers to the total value of all life and non life Claims paid for by the Nigerian insurance industry. It covers all the claims that the insurance industry paid to their clients for the periods under review.

\subsubsection{Dependent variables}

Insurance penetration: Signifies the level of development of insurance sector in a country. Penetration rate is measured as the ratio of premium underwritten in a particular year to the GDP. It refers to a product's sales volume relative to the sales volume of competing products in a country over a specific period of time.

Insurance Density: Insurance density is calculated as the ratio of premium (in Naira) to total population. Insurance Density - refers to number of policyholders by geographic area (Country, state etc.) usually expressed as a ratio of premium to population. The measure of insurance density reflects the level of development of the sector.

\subsection{Data analysis technique}

The data for the study were subjected to stationarity test. The Phillips-Perrons method was used. Thereafter, a test of Model adequacy was run.

This was estimated using Coefficient of Correlation (R) and Adjusted Coefficient of Determination (AR2) and Durbin Watson parameters. The Coefficient of Correlation (R) points to a high or low linear relationship between the dependent and independent variable. The Adjusted Coefficient of Determination (AR2) is a modified version of R2.

It indicates how well terms fit a curve or line, but adjusts for the number of terms in a model. If you add more and more useless variables to a model, Adjusted R2 will decrease. If you add more useful variables, Adjusted R2 will increase. The Durbin Watson Statistic is a number that tests for autocorrelation in the residuals from a statistical regression analysis. The Hypotheses for the study were tested using Ordinary Least Squares (OLS). 
ANALYSIS OF DATA

\subsection{Analysis of Data}

\subsubsection{Test of Hypothesis one}

Restatement of Hypothesis one

$\mathrm{Ho}=$ Total claims settlement had not impacted positively and significantly on Insurance penetration in Nigerian.

$\mathrm{H} 1=$ Total claims settlement had impacted positively and significantly on Insurance penetration in Nigerian.

Decision Rules: Accept alternate hypothesis if p-value of (t-statistic) is less than (0.05) level of significance, otherwise reject alternate hypothesis and accept the null hypothesis.

Estimated Model Result for Hypothesis one Using the extract of results from appendix 1 for test of hypothesis one, the OLS regression result of IP on TIC shows that the Adjusted Coefficient of Determination (AR2) was -.097; the t-statistic was 0.540 and its p-value was [0.606]. (See appendix 1). Since the level of significance [0.05] was less than the p-value [0.606], the null hypothesis was accepted.

Conclusion: Based on the above analysis, we therefore conclude that total claims settlement had not significantly impacted on Insurance penetration in Nigerian.

\subsubsection{Test of Hypothesis Two}

Restatement of Hypothesis Two

$\mathrm{Ho}=$ Total claims settlement had not impacted positively and significantly on Insurance density in Nigerian

$\mathrm{H} 1=$ Total insurance claims had impacted positively and significantly on Insurance density in Nigerian

Estimated Model Result for Hypothesis Two Using the extract of results from appendix 2 for test of hypothesis two, the OLS regression result of ID on TIC shows that the Adjusted Coefficient of Determination (AR2) was 0.619; the t-statistic was 3.744 and its p-value was [0.007]. (See appendix 2). Since the level of significance [0.05] was greater than the p-value [0.007], the alternate hypothesis was accepted.

Conclusion: based on the above analysis, there was strong statistical evidence to conclude that total insurance claims had impacted positively and significantly on Insurance density in Nigerian.

\subsection{Discussion of empirical results}

Discussion of the impact of total insurance claims on insurance penetration in Nigeria

The model specification for Hypothesis one has its Adjusted Coefficient of Determination $\left(\mathrm{AR}^{2}\right)$ as -.097. Given that $\left(\mathrm{AR}^{2}\right)$ is nearer to zero than one; the model is described as having a very poor fit to the analysis. In other words, only $4 \%$ of the total variation in insurance penetration in Nigeria could be explained by the Regression model.

The result further shows that independent variable (insurance claims) had a positive correlation coefficient of 0.200 with the dependent variable (insurance penetration). This depicts a low linear correlation between the variables. In other words, the strength of the relationship between them was weak. The Durbin Watson value of 1.057 shows a positive 
auto-correlation between the variables.

\section{Discussion of the impact of total insurance claims on insurance density in Nigeria}

The model specification for Hypothesis two has its Adjusted Coefficient of Determination $\left(\mathrm{AR}^{2}\right)$ as 0.619 . Given that $\left(\mathrm{AR}^{2}\right)$ is nearer to zero than one; the model is described as having a very good fit to the analysis. In other words, about $61.9 \%$ of the total variation in insurance density in Nigeria could be explained by the Regression model.

The result further shows that independent variable (insurance claims) had a positive correlation coefficient of 0.817 with the dependent variable (insurance density). This depicts a high linear correlation between the variables. In other words, the strength of the relationship between them was strong. The Durbin Watson value of 0.596 shows a positive autocorrelation between the variables.

\section{SUMMARY OF FINDINGS, CONCLUSION AND RECOMMENDATIONS 5.1 Summary of Findings}

Based on the analysis of data and test of hypotheses done in section four, the following were the findings of the study:

1. Total insurance claims had positively but insignificantly impacted on Insurance penetration in Nigerian. The correlation coefficient was 0.200 and the p-value was [0.606] at [0.05] level of significance.

2. Total insurance claims had impacted positively and significantly on Insurance density in Nigerian. The correlation coefficient was 0.817 and the p-value was [0.007] at [0.05] level of significance.

\subsection{Conclusion}

Bringing into line with the findings of the study, we therefore conclude that claims settlement had impacted positively on the development of Nigerian Insurance Industry for the periods reviewed. However, while the impact of total insurance claims on insurance density was found to be positive and significant, it was however, positive but insignificant on insurance penetration in Nigeria.

\subsection{Recommendations}

The following recommendations were made in line with the findings of the study: Insurance companies should have effective and efficient claims department equipped with modern technology and qualified claims manager(s) to oversee the management and settlement of valid claims of their policyholders in order to increase insurance penetration in Nigeria.

Nigerian Insurance Industry regulators should enhance its supervisory frameworks to ensure that genuine claims are promptly settled by insurance companies and defaulter adequately punished. This will have positive impact on insurance density because more Nigerians will be encouraged to buy insurance policies.

In line with the theoretical framework adopted for this study, and in addition to settlement of valid claims, insurance companies should periodically carry out marketing research to find out the insurance needs of their customers as well as prospective customers through product revitalization and new product development to increase customers' expected utility for buying insurance. This will encourage them to buy more insurance, and in return enhance the 
development of Nigerian Insurance industry.

\subsection{Contribution to Knowledge}

This study has shown how total insurance claims settlement had impacted on insurance penetration and insurance density in Nigerian. As such, the findings of this study will be vital to insurance practitioner, insurance industry regulators and will provide a source of literature to future researchers in respect of impact of insurance claims and the development of Nigerian Insurance Industry.

\section{REFERENCES}

1. Afolabi, T. S. (2018). Effect of Claims Payments on Profitability in the Nigerian Insurance Industry. Advances in Social Sciences Research Journal, 5(4) 94-101.

2. Agu, K.O.C. (1999). Claims Settlement in Nigeria. Enugu, Immaculate Publications Ltd.

3. Ahuja, R. (2004). Insurance: over the transition, Economic and Political Weekly.

4. Ajemunigbohun, S. \&Oreshile,G. (2014). Insurance Fraud: Issues and Challenges. The Geneva Papers on Risk and Insurance 29 (2).

5. Barry, C. (2011). Importance of Claims Management in Insurance Sector. Retrieved From www.ehow.com/.

6. Bates, I. \& Atkins, B. (2007). Management of Insurance Operations. London, Global Professional Publishing.

7. Braers, S. \& Francis, P. (2004). Cutting the Cost of Insurance Claims: Taking Control of the Process. Booz and Company Media Uploads. Retrieved fromhttp://www.booz.com.

8. Butler, S. \& Francis, P. (2010). Cutting the Cost of Insurance Claims, taking control of the process. NY, Booz \& Co.

9. Cambridge Business Dictionary (2019) Definition of "development". UK; Cambridge University Press.

10. Daniel, F. (2013).Prompt Claim Settlement, the Best Advert for Insurance Firms. http://www.thisdaylive.com/articles/

11. Harry, R. (2012). Transforming Claims Management with Communication and Collaboration Technology. An Insurance Industry Thought-Leadership Paperon Behalf of Csco. Retrieved from www.cisco.com

12. Hewitt, Y.A. (2006). Towards Effective Risk Management in the Insurance industry. Claims Club Meeting. London, United Kingdom: Post Magazine.

13. Jeff, R. (2016). How is insurance penetration Different from insurance density? http//.www.Quora.com. Retrieved on $15^{\text {th }}$ June, 2019.

14. Kalani, M., Salunkhe, H. A., \& Ahirrao, M. B. (2013).Comparative study of claim settlement ratio of LIC with other insurance companies in India. Indian Journal of Applied Research, 3 (5), 389-391.

15. Kapoor, A. (2008). Strategic Perspectives Off-shoring Claims; the View within the Insurance Industry. (Master dissertation), Nottingham University Business School

16. Marquis, N. A (2011). Chartered Insurance Institute (CII) Course Book, Insurance Claims Handling Process, CII Learning Solutions.

17. Ndubuishi, M. O. (2008). Management of Insurance Business in Nigeria, retrieved on 23/02/2010from: http://findarticles.com/p/articles/

18. Nwite, S. C. (2005). Element of Insurance. Enugu, Immaculate Publication Nigeria Ltd.

19. Oluoma, R. O. (1999). Elements of Insurance. Lagos, Impressed Publishers.

20. Omar, O. E. (2005). The Retailing of life insurance in Nigeria: An assessment of consumers attitude. Journal of Retail Marketing Management Research, 1(1), 41-47.

21. Onifade, N. (2016). How is insurance penetration different from insurance density? http//.www.Quora.com. Retrieved on $15^{\text {th }}$ June, 2019. 
22. Oshinloye , M. O. (2009). The Impact of Insurance Activities on Economic growth. International Journal of Business and Commerce. 3(10).

23. Peverett, E. (1993). Fire Insurance Laws and Claims. London: Chartered Institute of Loss Adjusters.

24. Rastogi, S. \& Shankar, R. (2007). Enhancing Competitiveness: The Case of the Indian Life Insurance Company, Kozhikode, Indian Institute of Management.

25. Rejda, G.E. (2008). Principles of Risk Management and Insurance. 10th ed. New York, Pearson Education.

26. Singh, H.B. (2010). Banking and Insurance. Kathmandu, Asia Publication.

27. Ujunwa, A. \& Modebe, N. J. (2011). Repositioning Insurance Industry for Operational Efficiency: The Nigerian Case, Journal of Applied Finance \& Banking, 1 (3).

28. Unachukwu, J. C, Afolabi, M.A, Alabi, E. (2015). Effect of Prompt Claims Settlement on the Performance of Nigeria Insurance Industry. International Journal inManagement and Social Science. 3(4).

29. Viswanadham $P$ (2005). Claims settlement operations performance evaluation of LIC of India. The Indian Journal of Commerce, 58(2), 80-90.

30. Williams, R. (2009). Reassessing the Fundamentals and Beyond: Ronald Coase, the Transaction Cost and Resource Based Theories of the Firm and the Institutional Structure of Production. Strategic Management Journal, 23(6): 535-550.

31. Yusuf, T. O. \& Dansu, F. S. (2014). Effect of Claim Cost on Insurer's profitability in Nigeria. International Journal of Business and Commerce. 3(10).

32. Yusuf, T. O. (2013). Investigating the Roles of Claims Manager in Claims Handling Process in the Nigeria Insurance Industry. Journal of Business Finance. 1 (2); 69. 